Науковий вісник НЛТУ України
Scientific Bulletin of UNFU
$\begin{gathered}\text { http://nv.nltu.edu.ua } \\ \text { https://doi.org/10.36930/40291007 }\end{gathered}$

С. І. Миклуш, П. Г. Хомюк, С. А. Гаврилюк

Національний лісотехнічний університет Украӥни, м. Львів, Украӥна

\title{
ЛІСІВНИЧА ОСВІТА І НАУКА В НАЦІОНАЛЬНОМУ ЛІСОТЕХНІЧНОМУ УНІВЕРСИТЕТІ УКРАЇНИ: ЗДОБУТКИ, ПРОБЛЕМИ, ПЕРСПЕКТИВИ
}

\begin{abstract}
Після відновлення навчання в лісотехнічному інституті підготовка фахівців в інституті лісового і садово-паркового господарства (на лісогосподарському факультеті) постійно удосконалювалась. На факультеті у 60-х роках XX ст. навчалося близько 600 студентів, а на січень 2018 р. в університеті навчаються майже тисяча студентів на бакалаврському та магістерському рівнях за трьома спеціальностями та чотирма освітньо-професійними програмами: лісове господарство, садовопаркове господарство, мисливське господарство, ландшафтна архітектура. Підготовку фахівців для лісової галузі забезпечує висококваліфікований навчально-науковий персонал - 17 докторів наук, професорів та 44 доценти, кандидати наук. Співробітники інституту з 1949 р. захистили 30 докторських та 168 кандидатських дисертацій. Результати наукових досліджень висвітлено в 95 монографіях, що опубліковано в Україні та 13 - за кордоном, а також у наукових статтях, виступах на конференціях і захистили патенти та авторські свідоцтва. Науковці опублікували майже 5,5 тис. статей у різних виданнях та майже 5 тис статей у фахових виданнях. Викладачі кафедр інституту викладають більше як половину дисциплін для освітнього ступеня "бакалавр" та понад 75 \% - для освітнього ступеня "магістр" за спеціальністю "лісове господарство". Науково-педагогічні працівники університету є співавторами стандартів вищої освіти, проектів ДСТУ, проектів СОУ, нормативно-довідкових матеріалів, енциклопедій та словників. Наукові дослідження, що започаткували співробітники інституту беруть початок 31960 р., коли під керівництвом проф. М. М. Горшеніна було розроблено новий спосіб рубань головного користування для гірських умов - механізовані улоговинні рубки ЛЛТІ. Для розширення освітньої діяльності доцільно ліцензувати нові спеціальності з підготовки фахівців за спеціалізаціями, для розвитку яких у співробітників університету є значні напрацювання. Частина викладачів добре володіє іноземними мовами, проходили стажування у провідних європейських навчальних закладах, мають значний досвід викладання та можуть забезпечити викладання навчальних дисциплін іноземними мовами. Необхідно підвищувати ефективність роботи лабораторій кафедр та реалізацію наукових результатів на лісогосподарських підприємствах.
\end{abstract}

Ключові слова: студенти; підготовка фахівців; викладацький склад; навчально-методичне забезпечення; науково-дослідна робота; перспективи розвитку.

Вступ. У Львівському лісотехнічному інституті (3 1993 р. Український державний лісотехнічний університет, а з 2005 р. Національний лісотехнічний університет України) підготовку фахівців з лісового господарства розпочато у 1949 р. після становлення лісогосподарського факультету у складі двох кафедр та 131 студента на базі факультетів, які функціонували у Львівській Політехніці та аграрному інституті в Дублянах (Natsionalnyi lisotekhnichnyi ..., 2014).

У 1966 р. набір студентів на перший курс та, очевидно, і випуск спеціалістів у наступні роки становив 95 осіб денної форми навчання та 100 осіб - заочної (табл. 1). 31970 р. на перший курс щорічно зараховували по 125 осіб, а термін навчання становив від 4,5 до 5 років, переважно 4 роки та 7 місяців за денною формою навчання.

У 1993 р. на навчання за спеціальністю "Лісове господарство" було зараховано 119 осіб за денною та 84 особи за заочною формами навчання. На факультеті 31 вересня 1992 р. здійснено перший набір студентів за спеціальностями "Екологія" та "Ландшафтна архітектуpa". Отже, за денною формою навчання було 705 осіб, а за заочною - 406 осіб. Найбільша кількість студентів на факультеті навчалась на 1 жовтня 2002 р. - 1285 осіб денної форми.

На початку 2000-х років за денною та заочною формами навчання обсяг набору за спеціальностями та кваліфікаційними рівнями перевищував 300 осіб, зокрема у 2005 р. на перші курси на навчання за освітньо-професійними програмами (ОПП) бакалавр, спеціаліст та магістр зараховано 387 осіб, а загалом навчалось в інституті 1076 студентів за денною та 832 особи за заочною

\section{Інформація про авторів:}

Миклуш Степан Іванович, д-р с.-г. наук, професор, директор ННІ лісового і садово-паркового господарства. Email: msi_s@ukr.net; https://orcid.org/0000-0002-9762-1190

Хомюк Петро Григорійович, канд. с.-г. наук, доцент, кафедра лісової таксації та лісовпорядкування. Email: khompetro@ukr.net; https://orcid.org/0000-0003-4409-9180

Гаврилюк Сергій Анатолійович, канд. с.-г. наук, доцент, кафедра лісової таксації та лісовпорядкування. Email: serhiy_havrylyuk@nltu.edu.ua; https://orcid.org/0000-0003-0361-0624

Цитування за ДСтУ: Миклуш С. І., Хомюк П. Г., Гаврилюк С. А. Лісівнича освіта і наука в Національному лісотехнічному університеті України: здобутки, проблеми, перспективи. Науковий вісник НлтУ України. 2019, т. 29, № 10. С. 38-44.

Citation APA: Myklush, S. I., Khomiuk, P. H., \& Havryliuk, S. A. (2019). Forestry education and science in UNFU: achievements, problems and perspectives. Scientific Bulletin of UNFU, 29(10), 38-44. https://doi.org/10.36930/40291007 
формами навчання. Унаслідок різних причин (демографічної ситуації та відкриття підготовки фахівців за спеціальністю "Лісове господарство" в непрофільних навчальних закладах, зокрема педагогічних), кількість студентів в університеті у 2017 р., порівняно з 2005 р., зменшилась майже у два рази і на 1 жовтня 2017 р. становила 941 студент, з яких 504 особи денної форми навчання.

Кращі студенти інституту в 70-80-их роках навчались у вищих навчальних закладах Польщі та Німеччини, 3 початку 2000 р. 8 студентів інституту завершили магістерський курс у Шведському аграрному університеті, а 32015 р. 1-2 студенти кожного семестру навчаються в Університеті сталого розвитку Еберсвальде (Нiмеччина).

В інституті випуск фахівців, який з початку 2000 p. перевищує щорічно 270 осіб за денною формою та є в межах 170-260 осіб за заочною формою навчання, перевищив 15 тис. фахівців освітньо-кваліфікаційного рівня (ОКР) "спеціаліст" та освітнього ступеня (ОС) "магістр" за спеціальністю "Лісове господарство".

Табл. 1. Контингент студентів інституту (бакалавр+спеціаліст+магістр)

\begin{tabular}{|c|c|c|c|c|c|c|c|c|c|c|}
\hline \multirow{2}{*}{ Спеціальність } & $1966 \mathrm{p}$. & \multicolumn{3}{|c|}{$1993 \mathrm{p}$} & \multicolumn{3}{|c|}{$2005 \mathrm{p}$} & \multicolumn{3}{|c|}{2017 p. } \\
\hline & прийом & прийом & навчається & випуск & прийом & навчається & випуск & прийом & навчається & випуск \\
\hline \multicolumn{11}{|c|}{ Денна форма навчання } \\
\hline $\begin{array}{c}\text { Лiсове } \\
\text { господарство }\end{array}$ & 95 & \multirow{3}{*}{119} & \multirow{3}{*}{579} & \multirow{3}{*}{133} & $\begin{array}{c}118+ \\
89+ \\
15\end{array}$ & $\begin{array}{c}389+ \\
160+ \\
34\end{array}$ & $\begin{array}{c}98+ \\
93+ \\
3\end{array}$ & $\begin{array}{c}83+ \\
0+ \\
45\end{array}$ & $\begin{array}{c}221+ \\
0+ \\
73\end{array}$ & $\begin{array}{c}154+ \\
37+ \\
23\end{array}$ \\
\hline $\begin{array}{c}\text { Садово-паркове } \\
\text { господарство }\end{array}$ & - & & & & $\begin{array}{c}29+ \\
16\end{array}$ & $\begin{array}{c}90+ \\
35\end{array}$ & $\begin{array}{c}16+ \\
19\end{array}$ & $\begin{array}{c}15+ \\
0+ \\
15\end{array}$ & $\begin{array}{c}53+ \\
0+ \\
22\end{array}$ & $\begin{array}{c}22+ \\
4+ \\
6\end{array}$ \\
\hline $\begin{array}{c}\text { Мисливське } \\
\text { господарство }\end{array}$ & - & & & & 18 & 62 & 9 & $\begin{array}{c}1+ \\
0+ \\
3\end{array}$ & $\begin{array}{c}16+ \\
0+ \\
4\end{array}$ & $\begin{array}{c}5+ \\
0 \\
4\end{array}$ \\
\hline $\begin{array}{c}\text { Ландшафтна } \\
\text { архітектура }\end{array}$ & - & 27 & 56 & - & $\begin{array}{c}32+ \\
12\end{array}$ & $\begin{array}{c}162+ \\
11\end{array}$ & $\begin{array}{c}12+ \\
9\end{array}$ & $\begin{array}{c}13+ \\
0+ \\
10\end{array}$ & $\begin{array}{c}98+ \\
0+ \\
17\end{array}$ & $\begin{array}{c}22+ \\
15+ \\
6\end{array}$ \\
\hline Екологія & - & 39 & 70 & - & $\begin{array}{c}41+ \\
17\end{array}$ & $\begin{array}{c}119+ \\
16\end{array}$ & $\begin{array}{c}21+ \\
20\end{array}$ & - & - & - \\
\hline Разом & 95 & 185 & 705 & 133 & 387 & 1076 & 300 & 185 & 504 & 293 \\
\hline \multicolumn{11}{|c|}{ Заочна форма навчання } \\
\hline $\begin{array}{c}\text { Лiсове } \\
\text { господарство }\end{array}$ & 100 & \multirow{3}{*}{84} & \multirow{3}{*}{406} & \multirow{3}{*}{85} & $\begin{array}{c}200+ \\
129\end{array}$ & $\begin{array}{c}486+ \\
278\end{array}$ & $\begin{array}{c}122+ \\
99\end{array}$ & $\begin{array}{c}114 \\
+0 \\
+81\end{array}$ & $\begin{array}{c}356 \\
+0 \\
+100\end{array}$ & $\begin{array}{c}93+ \\
46+ \\
17\end{array}$ \\
\hline $\begin{array}{c}\text { Садово-паркове } \\
\text { господарство }\end{array}$ & & & & & $\begin{array}{c}0+ \\
6\end{array}$ & $\begin{array}{l}0+ \\
19\end{array}$ & - & $\begin{array}{l}11+ \\
0+4\end{array}$ & $\begin{array}{l}32+ \\
0+4\end{array}$ & $\begin{array}{c}10+3 \\
+4 \\
\end{array}$ \\
\hline $\begin{array}{c}\text { Мисливське } \\
\text { господарство }\end{array}$ & & & & & & & & $\begin{array}{c}0+ \\
0+2\end{array}$ & $\begin{array}{c}0+ \\
0+5\end{array}$ & - \\
\hline \multirow[t]{2}{*}{ Екологія } & & & & & 29 & 79 & 19 & & & \\
\hline & 100 & 84 & 406 & 85 & 364 & 832 & 240 & 212 & 437 & 173 \\
\hline Всього & 195 & 269 & 1111 & 218 & 751 & 1908 & 540 & 397 & 941 & 466 \\
\hline
\end{tabular}

Поряд із підготовкою спеціалістів за базовою спеціальністю на замовлення виробництва були підготовлені фахівці за певними спеціалізаціями (табл. 2). За окремими 3 них здійснено 2-3 випуски, а окремі спеціалізації переросли в інші спеціальності, наприклад: на основі спеціалізації "Озеленення населених місць" започатковано спеціальність 206 "Садово-паркове господарство".

Табл. 2. Перші випуски фахівців за спеціалізаціями

\begin{tabular}{|c|c|}
\hline Назва спеціалізації & Рік першого набору \\
\hline Озеленення населених місць & 1969 \\
\hline Лісова меліорація & 1974 \\
\hline Лісова таксація та лісовпорядкування & 1993 \\
\hline Мисливське господарство & 1993 \\
\hline
\end{tabular}

У лютому 2002 р. здійснено перший випуск магістрів лісового господарства, у 2010 р. - магістрів садовопаркового господарства, а магістрів з ландшафтної архітектури - 30.06.2008 р. У 2017 р. на навчання за освітнім ступенем (ОС) "магістр лісового господарства" зараховано 126 осіб, з них 45 осіб - на денну форму навчання.

У 1949 р. на факультеті функціонували дві кафедри: ботаніки і грунтознавства та лісівництва, таксації і геодезії, а вже у 50-х роках XX ст. підготовку фахівців на лісогосподарському факультеті забезпечували, як i сьогодні, п'ять кафедр. У 1955 р. функціонували кафедри: лісівництва, лісових культур та механізації лісогосподарських робіт, геодезії та лісової таксації, ботаніки та дендрології, а також захисту лісу та деревинознавства. На факультеті в той час працював один професор та вісім доцентів. Станом на 1993 р. підготовку фахівців за спеціальностями факультету забезпечували три кафедри чисельністю 56 викладачів, з яких 11 професорів та докторів наук та 30 доцентів. Частка науково-педагогічних працівників (НПП) 3 науковими ступенями становила 80,4 \%, а частка професорів - 19,6 \%. Кафедра генетики, лісових культур та деревинознавства на 100 \% укомплектована викладачами 3 науковими ступенями (табл. 3).

На 2005 р. чисельність викладачів зі збільшенням числа студентів факультету зросла до 72 осіб, з яких 9 професорів та 35 доцентів, кандидатів наук. Частка професорів зменшилась до $12,5 \%$, проте на двох кафедрах - лісових культур і лісової селекції та ботаніки, деревинознавства і недеревних ресурсів лісу - працювали лише викладачі 3 науковими ступенями. До 2017 р. істотно зросла частка викладачів 3 науковими ступенями - 88,7 \%, 3 яких понад 21 \% професори i доктори наук. Наближаються до 100 \% викладацького 
складу з науковими ступенями ще дві кафедри - лісівництва $(90$ \%) і лісової таксації та лісовпорядкування
(92 \%), на яких лише дві та одна особи відповідно без наукового ступеня.

Табл. 3. Зміна структури та чисельності кафедр інституту

\begin{tabular}{|c|c|c|c|c|c|c|c|}
\hline \multirow{2}{*}{ Рік } & \multirow{2}{*}{ Назва кафедри } & \multicolumn{5}{|c|}{ Чисельність НПП, осіб } & \multirow{2}{*}{$\begin{aligned} \text { Частка осіб } \\
3 \text { наук. ступ }\end{aligned}$} \\
\hline & & проф. & доц. & ст. викл. & асист. & разом & \\
\hline \multirow{5}{*}{1993} & Лісівництва, таксації та лісовпорядкування & 3 & 13 & 1 & 4 & 21 & 85,7 \\
\hline & $\begin{array}{l}\text { Генетики, лісових культур та деревинознав- } \\
\text { ства }\end{array}$ & 4 & 9 & 1 & 1 & 15 & 100 \\
\hline & $\begin{array}{l}\text { Екології, ландшафтної архітектури та садово- } \\
\text { паркового будівництва }\end{array}$ & 4 & 8 & 4 & 4 & 20 & 60 \\
\hline & Разом & 11 & 30 & 6 & 9 & 56 & 80,4 \\
\hline & У відсотках & 19,6 & 53,6 & 10,7 & 16,1 & - & - \\
\hline \multirow{7}{*}{2005} & Лісівництва & 3 & 11 & 1 & 6 & 21 & 71,4 \\
\hline & Лісової таксації та лісовпорядкування & 1 & 6 & 3 & 4 & 14 & 71,4 \\
\hline & Лісових культур і лісової селекції & 2 & 3 & 1 & 4 & 10 & 100 \\
\hline & $\begin{array}{l}\text { Ботаніки, деревинознавства і недеревних ре- } \\
\text { сурсів лісу }\end{array}$ & 1 & 6 & 1 & 3 & 11 & 100 \\
\hline & $\begin{array}{l}\text { Ландшафтної архітектури, садово-паркового } \\
\text { господарства та урбоекології }\end{array}$ & 2 & 5 & 4 & 5 & 16 & 43,75 \\
\hline & Разом & 9 & 31 & 10 & 22 & 72 & 80,6 \\
\hline & У відсотках & 12,5 & 43,1 & 13,9 & 30,6 & & \\
\hline \multirow{7}{*}{2017} & Лісівництва & 6 & 12 & 1 & 2 & 21 & 90,5 \\
\hline & Лісової таксації та лісовпорядкування & 4 & 7 & 1 & 1 & 13 & 92,4 \\
\hline & Лісових культур і лісової селекції & 2 & 7 & 1 & 1 & 11 & 100 \\
\hline & $\begin{array}{l}\text { Ботаніки, деревинознавства і недеревних ре- } \\
\text { сурсів лісу }\end{array}$ & 3 & 7 & 1 & - & 11 & 100 \\
\hline & $\begin{array}{l}\text { Ландшафтної архітектури, садово-паркового } \\
\text { господарства та урбоекології }\end{array}$ & 2 & 11 & 6 & 4 & 23 & 60,9 \\
\hline & Разом & 17 & 44 & 10 & 9 & 79 & 88,7 \\
\hline & У відсотках & 21,5 & 55,7 & 12,6 & 11,4 & - & - \\
\hline
\end{tabular}

Кваліфікований науково-педагогічний персонал інституту дав змогу забезпечити навчальний процес необхідною навчально-методичною літературою. Кафедри інституту забезпечують викладання 51,2% дисциплін для ОС "бакалавр" з лісового господарства та понад 75 \% - на ОС "магістр". Необхідно відзначити, що на ОС бакалавр усі 35 дисциплін обов'язкової частини забезпечені підручниками, навчальними посібниками чи практикумами, які підготували викладачі кафедр. Водночас 9 дисциплін обов'язкової та 24 дисципліни вибіркової частин ОС магістр забезпечені переважно конспектами лекції та на 50-85 \% підручниками та посібниками працівників інституту. Найбільше підручників та посібників підготував проф. В. П. Кучерявий, який $є$ автором та співавтором 13 видань.

Серед найуживаніших та найвідоміших підручників та посібників є такі: Фітопатологія (Shevchenko \& Tsyliuryk, 1986; Tsyliuryk \& Shevchenko, 2008), Лесоводство (Horshenyn \& Shvydenko, 1977), Лісові меліорації (Kalynyn, 1982), Недеревна продукція лісу (Riabchuk, 1996), Екологія (Kucheriavyi, 2000), Біометрія (Horoshko et al., 2004), Озеленення населених місць (Kucheriavyi, 2005), Лісові культури (Hordiienko et al., 2005), Біологія лісових птахів і звірів (Delehan et al., 2005), Ботаніка (Kolishchuk et al., 2010), Дендрологія (Zaiachuk, 2014).

На факультеті працювали "Заслужені діячі науки і техніки України" - професори М. М. Горшенін, С. А. Генсірук, Я. О. Сабан, С. В. Шевченко, П. В. Павлів та працює сьогодні в університеті проф. Г. Т. Криницький, а також "Лауреати державної премії України в галузі науки і техніки" - професори С. А. Генсірук та С. В. Шевченко.

Більше як половина НПП інституту пройшли тривалі стажування в навчальних закладах та наукових установах Європи (Польща, Німеччина, Іспанія, Румунія, Швеція, Словаччина) та США.
Високу кваліфікацію НПП визначають наукові дослідження, які виконали співробітники інституту і аспіранти, докторанти та здобувачі наукових ступенів під керівництвом провідних професорів і доцентів. Починаючи 31950 р., коли захистив кандидатську дисертацію Т. М. Бродович (Brodovych, 1950), до 2018 р. захищено 30 докторських та 168 кандидатських дисертацій. До 1993 р. було захищено 8 докторських дисертацій, а після 2005 р. - 19 (табл. 4). На цей період припадає також найбільша кількість захищених кандидатських дисертацій в інституті.

\section{Табл. 4. Захищені кандидатські та докторські} дисертації в розрізі кафедр інституту

\begin{tabular}{|c|c|c|c|c|c|}
\hline Кафедра & $\begin{array}{c}\text { Дисерта- } \\
\text { ція }\end{array}$ & \begin{tabular}{|c|} 
До 1993 \\
p.
\end{tabular} & $\begin{array}{c}1994- \\
2005 \mathrm{pp} .\end{array}$ & \begin{tabular}{|c|}
$2006-$ \\
$2017 \mathrm{pp}$.
\end{tabular} & Разом \\
\hline \multirow{2}{*}{ Лісівництва } & канд. & 6 & 13 & 26 & 45 \\
\hline & докт. & 2 & 2 & 9 & 13 \\
\hline \multirow{2}{*}{$\begin{array}{l}\text { Лісової такса- } \\
\text { ції та лісовпо- } \\
\text { рядкування }\end{array}$} & канд. & 18 & 11 & 15 & 44 \\
\hline & докт. & 3 & - & 3 & 6 \\
\hline \multirow{2}{*}{$\begin{array}{l}\text { Лісових куль- } \\
\text { тур і лісової се- } \\
\text { лекції }\end{array}$} & канд. & 17 & 6 & 15 & 38 \\
\hline & докт. & 1 & 1 & 1 & 3 \\
\hline \multirow{2}{*}{$\begin{array}{l}\text { Ботаніки дере- } \\
\text { винознавства і } \\
\text { недеревних ре- } \\
\text { сурсів лісу }\end{array}$} & канд. & 5 & 9 & 7 & 21 \\
\hline & докт. & 1 & - & 3 & 4 \\
\hline \multirow{2}{*}{$\begin{array}{l}\text { Ландшафтної } \\
\text { архітектури, } \\
\text { садово-парко- } \\
\text { вого господар- } \\
\text { ства та урбо- } \\
\text { екології }\end{array}$} & канд. & 2 & 9 & 9 & 20 \\
\hline & докт. & 1 & - & 3 & 4 \\
\hline \multirow{2}{*}{ Всього } & канд. & 48 & 48 & 72 & 168 \\
\hline & докт. & 8 & 3 & 19 & 30 \\
\hline
\end{tabular}


Найбільшу кількість дисертацій захищено з проблем ведення лісового господарства й оцінки лісових ресурсів та організації господарства в лісах. До 1993 р. важливими були проблеми штучного лісовідновлення та оцінки росту і продуктивності деревостанів, про що свідчить значна кількість робіт, захищених на кафедрі лісових культур лісової селекції та лісової таксації та лісовпорядкування. Результати наукових досліджень співробітників інституту оприлюднено в 108 монографіях, які опубліковано як в Україні, так і за кордоном (табл. 5).

Табл. 5. Кількість монографій, які опублікували науково-педагогічні працівники інституту

\begin{tabular}{|c|c|c|c|c|c|}
\hline Кафедра & Видання & $\begin{array}{c}\text { До } \\
1993 \text { p. }\end{array}$ & \begin{tabular}{|c|}
$\begin{array}{c}1994- \\
2005 \mathrm{pp} .\end{array}$ \\
\end{tabular} & $\begin{array}{c}2006- \\
2017 \text { pp. } \\
\end{array}$ & Разом \\
\hline \multirow[b]{2}{*}{ Лісівництва } & в Україні & 16 & 6 & 13 & 35 \\
\hline & $\begin{array}{c}\text { за кордо- } \\
\text { ном }\end{array}$ & - & 0,5 & 3 & 3,5 \\
\hline \multirow{2}{*}{$\begin{array}{l}\text { Лісової такса- } \\
\text { ції та лісовпо- } \\
\text { рядкування }\end{array}$} & в Україні & 4 & 1 & 2 & 7 \\
\hline & $\begin{array}{c}\text { за кордо- } \\
\text { ном }\end{array}$ & - & 2 & 2 & 4 \\
\hline \multirow{2}{*}{$\begin{array}{l}\text { Лісових куль- } \\
\text { тур і лісової се- } \\
\text { лекції }\end{array}$} & в Україні & 15 & 3 & 4 & 22 \\
\hline & $\begin{array}{c}\text { за кордо- } \\
\text { ном }\end{array}$ & - & - & - & - \\
\hline \multirow{2}{*}{$\begin{array}{l}\text { Ботаніки дере- } \\
\text { винознавства і } \\
\text { недеревних ре- } \\
\text { сурсів лісу }\end{array}$} & в Україні & 4 & 4 & 13 & 21 \\
\hline & $\begin{array}{c}\text { за кордо- } \\
\text { ном }\end{array}$ & - & 0,5 & 4 & 4,5 \\
\hline \multirow{2}{*}{$\begin{array}{l}\text { Ландшафтної } \\
\text { архітектури, } \\
\text { садово-парко- } \\
\text { вого господар- } \\
\text { ства та урбо- } \\
\text { екології }\end{array}$} & в Україні & 5 & 1 & 4 & 10 \\
\hline & $\begin{array}{c}\text { за кордо- } \\
\text { ном }\end{array}$ & - & - & 1 & 1 \\
\hline \multirow[b]{2}{*}{ Всього } & в Україні & 44 & 15 & 36 & 95 \\
\hline & $\begin{array}{c}\text { за кордо- } \\
\text { ном }\end{array}$ & - & 3 & 10 & 13 \\
\hline
\end{tabular}

Перші монографії було опубліковано у 1957 р. Їхні автори є С. В. Шевченко (Тополя) (Shevchenko, 1958), M. М. Горшенін, С. В. Шевченко (Horshenin \& Shevchenko, 1954) та С. А. Генсірук (Hensyruk, 1957). Найбільше, 15 монографій, вийшло із під пера проф. С. А. Генсірука (Hensyruk, 1957; Hensiruk, 1964; Hensiruk, 1971; Hensiruk \& Bondar, 1973; Hensiruk, 2002). 3aгалом до 1993 р. було опубліковано 44 монографії. Починаючи 32006 р. науковці університету опублікували 46 монографій, при чому 103 них за кордоном, переважно англійською мовою. Найбільше (39) монографій опублікували працівники кафедри лісівництва.

Результати наукових досліджень базуються на підсумках виконання наукових тем, що фінансуються за кошти державного бюджету та підприємств. На 1993 р. науковці інституту виконували 8 госпдоговірних тем загальним обсягом понад 4,6 млн купоно-карбованців. У 1993 р. під керівництвом проф. Г. Т. Криницького науковці виконували дослідження на тему "Розроблення селекційних і морфофізіологічних основ підвищення стійкості та продуктивності лісів зони відчуження ЧАEC" обсягом 2,9 млн купоно-карбованців. Найбільшу кількість держбюджетних розробок виконано в університеті у 2010 р. - 10 на загальну суму 511100 грн, а найбільшу річну суму - 530800 грн.

Найбільшу кількість госпдоговірних досліджень виконано в університеті у 2017 р. Основні напрями наукових досліджень кафедр інституту:

\section{1. Лісівництва:}

"Молекулярно-генетичні основи підвищення стійкості хвойних порід до найбільш небезпечних фітозахворювань";

"Розроблення методів і технологій покращення стану та реконструкції похідних ялинників Карпат".

\section{2. Лісової таксаиї та лісовпорядкування:}

"Динаміка вкритих лісовою рослинністю ділянок Українських Карпат за матеріалами дистанційного зондування Землі";

"Лісівничо-таксаційна та фітоценотична структура пралісів Українських Карпат як модель організації екологічно орієнтованого лісівництва".

3. Лісових культур і лісової селекиії:

"Селекційні основи відтворення генетичного потенціалу голонасінних та покритонасінних деревних інтродуцентів розмноженням in vitro";

"Дослідження морфологічних та стереометричних особливостей будови кореневих систем основних лісотвірних видів деревної рослинності".

4. Ботаніки, деревинознавства і недеревних ресурсів лісу:

"Розроблення заходів для збереження популяцій та підвищення продуктивності недеревних компонентів у лісових фітоценозах";

"Діагностування, кваліметрія та вирощування лісових деревних порід із заданими властивостями деревини".

5. Ландиафтної архітектури, садово-паркового господарства та урбоекологіі:

"Інвентаризація насаджень та проект реконструкції насаджень парку-пам'ятки садово-паркового мистецтва, парку, музею, міста";

"Проект реконструкції та ландшафтного облаштування парку".

Значних успіхів досягнули працівники лабораторії "Молекулярно-генетичних маркерів деревних рослин" (науковий керівник - д. б. н., проф. Р. Т. Гут), яку було створено в 2001 р. Науковці лабораторії розробили методику отримання препаратів антимікробних пептидів та методику раннього виявлення кореневої губки. У лабораторії отримали нуклеотидні послідовності двох генів сосни звичайної: дефензину PsDefl та ліпід-трансферного протеїну $n s L T P 1$, які зареєстрували у публічних базах даних GenBank (Hrunyk et al., 2012). Доценти кафедри лісової таксації та лісовпорядкування О.Г. Часковський та С. А. Гаврилюк працюють над виконанням європейської програми "Горизонт - 2020".

Результати наукових досліджень висвітлено в наукових статтях, виступах на конференціях і захищено патентами та авторськими свідоцтвами. Загалом науковці кафедр інституту опублікували майже 5,5 тис. статей у різних виданнях та майже 5 тис. статей у фахових виданнях загальним обсягом понад 3 тис. друкованих аркушів. Найбільшу кількість статей опубліковано з 2006 по 2017 pp. - понад 5,6 тис., 3 яких понад 2,6 тис. у фахових виданнях (табл. 6).

Як видно $з$ наведених даних, чисельність наукових статей не завжди корелює з чисельністю науковців кафедри. Починаючи 32004 р., науковці університету публікують результати досліджень у виданнях, що включені до наукометричних баз Scopus та Web of Science. Таких статей на квітень 2018 р. - 68, співавторами яких є 22 науковці.

Співавторами п'яти та більше наукових статей у виданнях, які включені до наукометричних баз Scopus та Web of Science, $є$ В. Ковальова, Т. Гут, О. Часковський, В. Куриляк, В. Крамарець, І. Мацях. Найбільше статей (34) у цих виданнях опублікували науковці кафедри лісівництва, дещо менше праць (21) опублікували співробітники кафедри лісової таксації та лісовпорядкування. 
Докторант кафедри лісівництва В. А. Ковальова $є$ співавтором 17 наукових статей у виданнях, що включені до наукометричної бази Scopus та Web of Science 3 iндексом Гірша в Scopus та Web of Science - 3, а найвищий показник індексу Гірша $(h=7) \in$ в доцента кафедри лісової таксації та лісовпорядкування О.Г. Часковського.
Співробітники інституту беруть активну участь в університетських, всеукраїнських та міжнародних конференціях. За підсумками університетських та Всеукраїнських конференцій опубліковано майже 900 тез та матеріалів конференцій обсягом 126 друкованих аркушів (табл. 7).

Табл. 6. Наукові статті, які опублікували науковці кафедр

\begin{tabular}{|c|c|c|c|c|c|c|}
\hline Кафедра & Рік & $\begin{array}{c}\text { Кількість } \\
\text { статей }\end{array}$ & $\begin{array}{l}\text { Обсяг, } \\
\text { др. арк. }\end{array}$ & $\begin{array}{l}\text { Кількість статей у } \\
\text { фахових виданнях }\end{array}$ & $\begin{array}{l}\text { Обсяг, } \\
\text { др. арк. }\end{array}$ & $\begin{array}{c}\text { Кількість статей } \\
\text { y Scopus }\end{array}$ \\
\hline \multirow{3}{*}{ Лісівництва } & до 1993 & 54 & 22,4 & 10 & 3,2 & - \\
\hline & 1994-2005 & 114 & 43,9 & 93 & 3,2 & - \\
\hline & 2006-2017 & 398 & 135,0 & 297 & 3,2 & $34(12)$ \\
\hline \multirow{3}{*}{$\begin{array}{l}\text { Лісової таксації } \\
\text { та лісовпорядкування }\end{array}$} & до 1993 & 34 & 10,6 & 23 & 7,8 & - \\
\hline & 1994-2005 & 105 & 22,7 & 109 & 33,6 & - \\
\hline & $2006-2017$ & 217 & 17,3 & 217 & 115,0 & $21(6)$ \\
\hline \multirow{3}{*}{$\begin{array}{l}\text { Лісових культур і лісової } \\
\text { селекції }\end{array}$} & до 1993 & 364 & 168,6 & 326 & 150,6 & - \\
\hline & 1994-2005 & 178 & 59,9 & 159 & 51,6 & - \\
\hline & 2006-2017 & 485 & 121,3 & 477 & 118,9 & - \\
\hline \multirow{3}{*}{$\begin{array}{l}\text { Ботаніки деревинознавства і } \\
\text { недеревних ресурсів лісу }\end{array}$} & до 1993 & 203 & 62,05 & 76 & 23,1 & - \\
\hline & 1994-2005 & 131 & 45,8 & 114 & 37,9 & - \\
\hline & $2006-2017$ & 226 & 87,6 & 262 & 99,3 & $13(4)$ \\
\hline \multirow{3}{*}{$\begin{array}{l}\text { Ландшафтної архітектури, } \\
\text { садово-паркового господарства та } \\
\text { урбоекології }\end{array}$} & до 1993 & 31 & 11,4 & 19 & 6,1 & - \\
\hline & 1994-2005 & 182 & 69,7 & 155 & 59,3 & - \\
\hline & $2006-2017$ & 331 & 127,4 & 308 & 114,2 & - \\
\hline \multirow{3}{*}{ Разом } & до 1993 & 710 & 242 & 630 & 185,6 & - \\
\hline & 1994-2005 & 1657 & 488,6 & 1561 & 450,6 & - \\
\hline & $2006-2017$ & 3053 & 1005,65 & 2645 & 827 & - \\
\hline Всього & & 5420 & 1736,25 & 4836 & 1463,2 & $68(22)$ \\
\hline
\end{tabular}

Табл. 7. Участь науково-педагогічних працівників університету в конференціях

\begin{tabular}{|c|c|c|c|c|c|c|c|}
\hline \multirow{3}{*}{ Кафедра } & \multirow{3}{*}{ Роки } & \multirow{2}{*}{\multicolumn{2}{|c|}{$\begin{array}{c}\text { Всеукраїнські } \\
\text { та університетські }\end{array}$}} & \multicolumn{4}{|c|}{ Міжнародні } \\
\hline & & & & \multicolumn{2}{|c|}{ в Україні } & \multicolumn{2}{|c|}{ за кордоном } \\
\hline & & $\begin{array}{c}\text { к-сть тез, } \\
\text { матеріалів }\end{array}$ & $\begin{array}{c}\text { обсяг, } \\
\text { др. арк. }\end{array}$ & $\begin{array}{l}\text { к-сть тез, } \\
\text { матеріалів }\end{array}$ & $\begin{array}{c}\text { обсяг, } \\
\text { др. арк. }\end{array}$ & $\begin{array}{l}\text { к-сть тез, } \\
\text { матеріалів }\end{array}$ & $\begin{array}{l}\text { обсяг, } \\
\text { др. арк. }\end{array}$ \\
\hline \multirow{3}{*}{ Лісівництва } & до 1993 & 44 & 3,7 & 7 & 1,3 & - & - \\
\hline & 1994-2005 & 53 & 6,7 & 61 & 7,5 & 19 & 3,2 \\
\hline & 2006-2017 & 104 & 13,3 & 142 & 24,8 & 144 & 11,1 \\
\hline \multirow{3}{*}{$\begin{array}{l}\text { Лісової таксації та } \\
\text { лісовпорядкування }\end{array}$} & до 1993 & 20 & 3,8 & 6 & 0,7 & 4 & 0,5 \\
\hline & 1994-2005 & 26 & 4,8 & 30 & 3,9 & 6 & 0,7 \\
\hline & $2006-2017$ & 103 & 16,1 & 115 & 11,8 & 19 & 1,3 \\
\hline \multirow{3}{*}{$\begin{array}{l}\text { Лісових культур і лісової } \\
\text { селекції }\end{array}$} & до 1993 & 46 & 3,5 & 25 & 3,5 & 6 & 1,2 \\
\hline & 1994-2005 & 34 & 2,4 & 127 & 10,8 & 46 & 3,7 \\
\hline & 2006-2017 & 46 & 3,7 & 246 & 13,2 & 54 & 4,6 \\
\hline \multirow{3}{*}{$\begin{array}{l}\text { Ботаніки деревинознавства i } \\
\text { недеревних ресурсів лісу }\end{array}$} & до 1993 & 34 & 4,8 & 36 & 3,8 & 13 & 2,6 \\
\hline & 1994-2005 & 40 & 7,75 & 51 & 9,75 & 18 & 3,5 \\
\hline & 2006-2017 & 114 & 19,15 & 143 & 20,7 & 52 & 8,1 \\
\hline \multirow{3}{*}{$\begin{array}{l}\text { Ландшафтної архітектури, } \\
\text { садово-паркового господар- } \\
\text { ства та урбоекології }\end{array}$} & до 1993 & 73 & 10,3 & 48 & 11,1 & 11 & 2,9 \\
\hline & 1994-2005 & 50 & 11,0 & 75 & 23,2 & 4 & 0,6 \\
\hline & $2006-2017$ & 78 & 15,6 & 181 & 44,3 & 31 & 13,5 \\
\hline \multirow{3}{*}{ Разом } & до 1993 & 217 & 26,1 & 122 & 20,4 & 34 & 7,2 \\
\hline & 1994-2005 & 203 & 32,65 & 344 & 55,15 & 93 & 11,7 \\
\hline & 2006-2017 & 445 & 67,85 & 827 & 114,8 & 300 & 38,6 \\
\hline Всього & - & 865 & 126,6 & 1293 & 190,35 & 427 & 57,5 \\
\hline
\end{tabular}

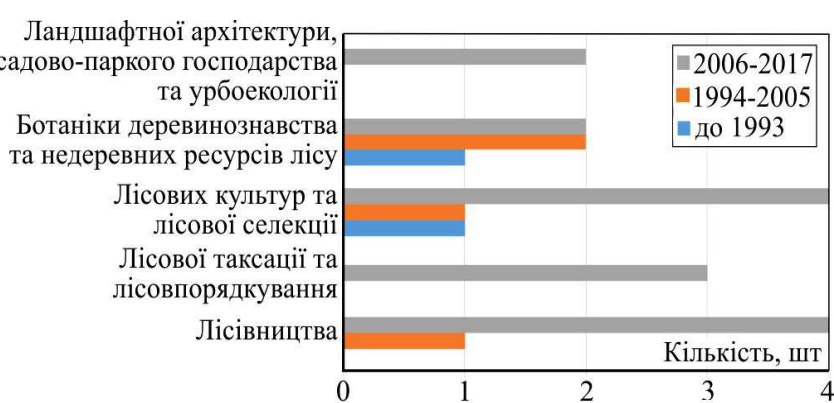

Рисунок. Охоронні документи на об'єкти інтелектуальної власності науковців інституту
Науковці інституту беруть участь у міжнародних конференціях в Україні (майже 1300 виступів) та за кордоном - понад 400 виступів. Нові підходи у вирішенні наукових та виробничих проблем, які запропонували науковцями захищені охоронними документами на об'єкти інтелектуальної власності. Так, вони отримали 19 патентів чи авторських свідоцтв (рисунок).

Найбільше (6) таких документів отримали науковці кафедри лісових культур і лісової селекції, а проф. I. C. Вінтонів одним із перших на факультеті у 1976 р. отримав патент на корисну модель. Науково-педагогічні працівники інституту є співавторами стандартів вищої 
освіти, проектів ДСТУ, проектів СОУ, нормативно-довідкових матеріалів, енциклопедій та словників.

В останні роки значно активізувалась міжнародна співпраця 3 науковими та навчальними установами Швейцарії, Німеччини, Австрії, Польщі, Чехії, Румунії та США. Викладачі та студенти університету брали участь у спільних із швейцарськими фахівцями та студентами дослідженнях букових пралісів Карпат, чеськими колегами - дослідженнях ялинових старовікових насаджень, німецькими - дослідженнями зміни структури лісових земель Полісся, польськими - дослідження структури дубового рідколісся. Результати спільних досліджень оприлюднено на наукових конференціях в Україні та за кордоном.

Наукові дослідження, які започаткували співробітники інституту беруть початок з 1960 р., коли під керівництвом проф. М. М. Горшеніна було розроблено новий спосіб рубань головного користування для гірських умов - механізовані улоговинні рубки ЛЛТІ (Horshenyn, \& Shvydenko, 1977). Найбільш знакові лісівничі дослідження співробітників інституту наведено в табл. 8.

Табл. 8. Найпомітніші лісівничі дослідження та роботи $1960-$ Під керівництвом проф. М. М. Горшеніна розроблено 1966 новий спосіб рубань для гірських умов - механізовані pp. улоговинні рубки ЛЛТІ.

Започатковано експериментальні дослідження віднов-

1963 лення сосново-дубових деревостанів природним шляхом у складних лісорослинних умовах (під кер. проф. М. М. Горшеніна).

1975 Створення Державного заказника "Страдчанський ліс".

1984 Закладено географічні культури (32 повторності) сосни звичайної у Страдчівському НВЛК на площі 16 га.

1990 Створено лабораторію "Експрес аналізу грунтів". Введено в експлуатацію "Музей деревини", де експо-

1991 нується колекція зразків деревини, яку зібрала Євстахій Волощак.

На виконання загальноєвропейської програми на площі

19952,5 га створено географічні культури бука лісового, які включають 70 географічних варіантів з різних європейських країн.

2001 На кафедрі лісівництва створено лабораторію молекулярно-генетичних маркерів деревних рослин.

3 Для реформування лісового господарства на засадах

2001 наближеного до природи лісівництва закладено 8 науково-виробничих стаціонарів.

2011 Відкриття ННВ лабораторії сучасних технологій лісокультурного виробництва.

Гербарій Національного лісотехнічного університету

2011 України одержав міжнародний акронім LWFU і внесений до реєстру національних гербаріїв України.

В університеті проходила міжнародна наукова конференція: "Букові праліси: природний еталон для управління і збереження біорізноманіття, лісових ресурсів та екосистемного сервісу". У роботі конференції взяли участь 152 учасників, 3 них 110 осіб із 23 зарубіжних країн.

Дослідження особливостей відновлення деревних порід, оцінювання їхнього росту і розвитку та продуктивності продовжуються. Сьогодні співробітники університету та працівники з виробництва під керівництвом проф. Г. Т. Криницького для реформування лісового господарства на засадах наближеного до природи лісівництва заклали 8 науково-виробничих стаціонарів у соснових, букових, дубових та ялицевих насадженнях Західного регіону (Krynytskyi, Lavnyi, \& Tselen, 2012).

Студенти інституту під керівництвом завідувача кафедри лісівництва В.В.Лавного вже 11 років поспіль вивчають досвід наближеного до природи ведення лісового господарства в лісах Німеччини, а студенти німецьких університетів знайомляться з пралісами Карпат.

Складна економічна ситуація, що зумовлена військовою агресією Росії, не визначена лісова політика держави, що позначились на зниженні іміджу лісівників, зумовили низку проблемних питань в освітньому просторі вищої школи та підготовці висококваліфікованих фахівців для лісового господарства, зокрема:

- незначна частка випускників продовжує навчання в аспірантурі, що позначиться на віковій структурі науково-педагогічних працівників;

- за спеціальностями інституту не навчаються іноземні студенти;

- потребує оновлення матеріально-технічна база кафедр найсучаснішими приладами та інструментами;

- необхідно ширше популяризувати наукові дослідження співробітників інституту шляхом опублікування монографій та наукових статей за кордоном у відомих виданнях, що включені до наукометричних баз Scopus та Web of Science.

Для розширення освітньої діяльності доцільно ліцензувати нові спеціальності з підготовки фахівців за освітньо-професійними програмами, для розвитку яких у співробітників інституту є певні напрацювання, зокрема це такі спеціальності (освітні програми):

• 132 "Матеріалознавство" ("Деревинознавство");

• 202 "Захист і карантин рослин" ("Захист лісових та декоративних рослин");

• 203 "Садівництво та виноградарство" ("Горіхівництво");

• 208 "Агроінженерія" ("Заготівля та переробка лісонасінної сировини", "Заготівля та переробка недеревної продукції лісу").

Певна частина викладачів добре володіють іноземними мовами, зокрема англійською, проходили стажування у провідних європейських навчальних закладах, мають значний досвід викладання. Вони можуть розробити курси навчальних дисциплін іноземними мовами, а в університет залучати до навчання іноземних студентів.

Доцільно також урізноманітнювати форми навчання, активізувати роботу з підготовки електронних навчальних видань, навчальних матеріалів дистанційної освіти та забезпечити підготовку фахівців за цією формою навчання.

Важливо ширше використовувати науковий потенціал, напрацювання співробітників університету, збільшувати обсяг базового держбюджетного фінансування, підвищувати ефективність роботи лабораторій кафедр та реалізацію наукових результатів через виконання госпдоговірних розробок на замовлення лісогосподарських підприємств галузі.

\section{References}

Brodovych, T. M. (1950). Douglas fir in plantations of USSR. Abstract of candidate dissertation for biology sciences. Lviv, $20 \mathrm{p}$. [In Russian].

Delehan, I. V. (Ed.), \& Delehan, I. I. (2005). Biology of forest birds and animals. Lviv: Polli, 600 p. [In Ukrainian].

Hensiruk, S. A. (1964). Forests of Ukrainian Carpathian and their using. Kyiv: Urozhai, 289 p. [In Ukrainian].

Hensiruk, S. A. (1971). Complex forestry in mounthians. Moscow: Lesnaia promyshlennost, 248 p. [In Russian].

Hensiruk, S. A. (2002). Ukrainian forests. Lviv, 496 p. [In Ukrainian]. 
Hensiruk, S. A., \& Bondar, V. S. (1973). Forest resouces of Ukraine, their reserving and using. Kyiv: Scientific thought, 526 p. [In Ukrainian].

Hensyruk, S. A., \& Tretyak, Yu. D. (Ed.). (1957). Fir stands of East Carpathian. Lviv: Lviv Polytechnic Institute, 128 p. [In Ukrainian].

Hordiienko, M. I., Huz, M. M., Debryniuk, Yu. M., \& Maurer, V. M. (2005). Forest plantations. Lviv: Kamula, 608 p. [In Ukrainian].

Horoshko, M. P., Myklush, S. I., \& Khomiuk, P. H. (2004). Biometry. Lviv: Kamula, 236 p. [In Ukrainian].

Horshenin, M. M., \& Shevchenko, S. V. (1954). The experience of reconstruction of not valuable forest stands. Lviv: Book and magazine publishing house, $38 \mathrm{p}$. [In Ukrainian].

Horshenyn, N. M., \& Shvydenko, A. Y. (1977). Forest silviculture. Lviv: Higher school, 303 p. [In Russian].

Hrunyk, N., Kovaleva, V., \& Gout, R. T. (2012). Patterns of expression of lipid-transfer protein gene in organs of Scots pine (Pinus

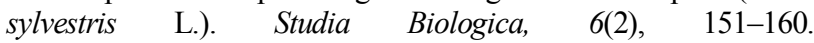
https://doi.org/10.30970/sbi.0602.210

Kalynyn, M. Y. (1982). Forest melioration in conditions of erosion relief. Lviv: Higher school, 279 p. [In Russian].

Kolishchuk, V. H., Soroka, M. I., \& Yuskevych, T. V. (2010). Botany. Lviv: Svit, 507 p. [In Ukrainian].
Krynytskyi, H. T., Lavnyi, V. V., \& Tselen, Ya. P. (2012). System of selective loggings in silviculture - theory, practice and perspectives for Ukraine. Scientific reports of the National University of Bioresources and Natural Resources of Ukraine. Ser. Arboriculture and Ornamental Horticulture, 171, 38-48. [In Ukrainian].

Kucheriavyi, V. P. (2001). Ecology. Lviv: Svit, 500 p. [In Ukrainian].

Kucheriavyi, V. P. (2005). Planting of greenery in urban places. Lviv: Svit, 456 p. [In Ukrainian].

Riabchuk, V. P. (1996). Non-timber wood products. Lviv: Svit, 312 p. [In Ukrainian].

Shevchenko, S. V. (1958). Poplar tree. Lviv: Lviv Regional Department of Agriculture, $105 \mathrm{p}$. [In Ukrainian].

Shevchenko, S. V., \& Tsyliuryk, A. V. (1986). Forest phytopathology. Kyiv: Higher school, 381 p. [In Russian].

Tsyliuryk, A. V., \& Shevchenko, S. V. (2008). Forest phytopathology. Kyiv: KVITS, 464 p. [In Ukrainian].

Tunytsia, Yu. Yu. (Ed.). (2014). Ukrainian National Forestry University: Historical presentation edition. Kyiv: TOV "Lohos Kyiv", 249 p. [In Ukrainian].

Zaiachuk, V. Ya. (2014). Dendrology. (2nd ed.). Lviv: Spolom, 676 p. [In Ukrainian].

S. I. Myklush, P. H. Khomiuk, S. A. Havryliuk

Ukrainian National Forestry University, Lviv, Ukraine

\section{FORESTRY EDUCATION AND SCIENCE IN UNFU: ACHIEVEMENTS, PROBLEMS AND PERSPECTIVES}

After restoration of education at Forestry Institute, training of specialists in the Institute of Forestry and Park Gardening (Faculty of Forestry in the past) has been constantly improved. In $1960 \mathrm{~s}$ there were almost 600 students studying in the Faculty of Forestry, whereas almost a thousand students of bachelor and master levels studied in the Institute in January 2018. There are three specialities and, accordingly, four education programs such as forestry, park gardening, hunting, and landscape architecture. Nowadays, highly qualified academic staff, namely 17 Doctors of Science, professors and 44 Philosophy Doctors, and assistant professors, provides training for forestry specialists. University academics have defended 30 Doctor of Science theses and 168 Philosophy Doctor theses since 1949. The results of scientific researches were published in 95 monographs in Ukraine and 13 - abroad. The results are also presented in papers and conference materials, and have patents and copyrights. The University scientists have publishes almost 5.5 thousand articles in various editions and almost 5 thousand articles in professional journals. Lecturers and professors of the Departments of the Institute provide more than half of the subjects for Bachelor degree and more than 75 per cent for Master's degree in forestry. They are co-authors of higher education standards, Federal standards, normative-reference materials, encyclopaedias and dictionaries. Scientific research started by the staff of the institute originated in 1960, when under the direction of prof. M. M. Gorshenin a new way of felling of the main use for mountainous conditions, i.e. mechanical valley felling LLTI was developed. In order to expand educational activity, it is reasonable to license new specialities for forestry specialists training. Teaching staff of the University have considerable developments to cope with that task. Some lecturers have a good command of foreign languages, they were trained in leading European higher education institutions, and they also have extensive teaching experience and can provide teaching disciplines in foreign language. It is necessary to increase the effectiveness of department laboratories and implementation of scientific results in forestry enterprises.

Keywords: students; training of specialists; university staff; educational and methodological support; research work; perspectives of development. 